\title{
Nutrient Content, Protein Fractionation, and Utilization of Some Beans as Potential Alternatives to Soybean for Ruminant Feeding
}

\author{
A. Jayanegara ${ }^{a, *}$, S. P. Dewi ${ }^{b}, \&$ M. Ridla ${ }^{a}$ \\ aDepartment of Animal Nutrition and Feed Technology, Faculty of Animal Science, Bogor Agricultural University \\ ${ }^{\mathrm{b}}$ Graduate School of Animal Nutrition and Feed Science, Bogor Agricultural University \\ Jalan Agatis, Kampus IPB Darmaga, Bogor 16680, Indonesia \\ (Received 27-06-2016; Reviewed 05-08-2016; Accepted 06-10-2016)
}

\begin{abstract}
This experiment aimed to determine nutrient content, protein fraction, and in vitro rumen fermentation of some alternative beans in comparison to soybean. Samples used were napier grass, soybean, redbean, groundnut, pigeonpea, cowpea, bambarabean, and mungbean. Samples were determined for their proximate composition, Van Soest's fiber fraction, and Cornell protein fraction. The samples were subsequently evaluated for their fermentation characteristics and digestibility by using a two-stage in vitro rumen fermentation technique, maintained at $39{ }^{\circ} \mathrm{C}$ for $2 \times 48 \mathrm{~h}$. The in vitro incubation was performed in three consecutive runs by following a randomized complete block design in which each sample per run was represented by four fermentation tubes. Results revealed that all experimental beans contained high crude protein (CP), i.e. above $200 \mathrm{~g} / \mathrm{kg}$ dry matter (DM), but only soybean and groundnut had CP contents higher than $300 \mathrm{~g} / \mathrm{kg}$ DM. Redbean had the lowest crude fiber and acid detergent fiber contents among the beans. Soybean contained high proportion of rapidly degraded CP fraction, but low in slowly degraded and unavailable CP fractions. High proportion of slowly degraded CP fraction was found in redbean and bambarabean. Redbean, pigeonpea, cowpea, and mungbean were better than soybean, groundnut, and bambarabean with regard to DM degradability and DM digestibility values $(P<0.05)$. Concentration of total VFA was the highest in the incubation of redbean. It was concluded that groundnut, redbean, pigeonpea, cowpea, and mungbean have the potency to be used to substitute soybean for ruminant feeding.
\end{abstract}

Key words: bean, alternative feed, protein fraction, ruminant, rumen

\section{ABSTRAK}

Penelitian ini bertujuan untuk menentukan kandungan nutrien, fraksi protein, dan fermentasi rumen in vitro dari sejumlah kacang-kacangan alternatif kacang kedelai sebagai pakan ternak ruminansia. Bahan pakan yang digunakan dalam penelitian ini adalah rumput gajah, kacang kedelai, kacang merah, kacang tanah, kacang gude, kacang tunggak, kacang bogor, dan kacang hijau. Analisis komposisi proksimat, fraksi serat Van Soest, dan fraksi protein Cornell dilakukan pada bahan. Bahan kemudian dievaluasi secara in vitro dengan menggunakan teknik fermentasi rumen dua tahap pada suhu $39^{\circ} \mathrm{C}$ selama $2 \times 48 \mathrm{jam}$. Inkubasi in vitro dilakukan dalam tiga ulangan berdasarkan rancangan acak kelompok (masing-masing diwakili oleh empat tabung fermentasi). Hasil penelitian menunjukkan bahwa semua kacang-kacangan mengandung protein kasar (PK) yang tinggi, yakni lebih dari $200 \mathrm{~g} / \mathrm{kg}$ bahan kering (BK), namun hanya kacang kedelai dan kacang tanah yang lebih tinggi dari $300 \mathrm{~g} / \mathrm{kg}$ BK. Kacang merah memiliki kandungan serat kasar dan serat deterjen asam yang paling rendah di antara kacang-kacangan yang diuji. Kacang kedelai mengandung proporsi fraksi PK mudah terdegradasi yang tinggi, namun rendah fraksi yang lambat terdegradasi dan yang tidak tersedia. Fraksi PK lambat terdegradasi yang tinggi terdapat pada kacang merah dan kacang bogor. Kacang merah, kacang gude, kacang tunggak, dan kacang hijau memiliki degradasi dan kecernaan BK yang lebih tinggi dibandingkan dengan kacang kedelai, kacang tanah, dan kacang bogor $(P<0,05)$. Konsentrasi total VFA paling tinggi terdapat pada inkubasi kacang merah. Disimpulkan bahwa kacang tanah, kacang merah, kacang gude, kacang tunggak, dan kacang hijau berpotensi untuk mensubstitusi kacang kedelai sebagai pakan ternak ruminansia.

Kata kunci: kacang-kacangan, pakan alternatif, fraksi protein, ruminansia, rumen

${ }^{*}$ Corresponding author:

E-mail: anuraga.jayanegara@gmail.com 


\section{INTRODUCTION}

Adequate and balance nutrients are necessary to ensure optimal livestock production and health, including energy and protein supply. Typically, in Indonesia and elsewhere, energy demand of livestock is relatively easier to meet from feed rather than protein demand, causing unbalance supply between energy and protein. The use of protein supplements is a common approach to overcome such insufficient protein supply. Soybean, either fullfat or defatted soybean (soybean meal), has been used as a main protein supplement for monogastric and ruminant animals in many regions of the world (Campos et al., 2014; Jolazadeh et al., 2015; Liu et al., 2016) including in Indonesia (Akhsan et al., 2015; Faradillah et al., 2015). Among protein supplements originated from plant sources, soybean is considered as superior with regard to its protein content and quality. Protein contents of soybean and soybean meal are around 35\%-52\% DM (Vollmann, 2016). Protein in soybean is highly digestible and rich in lysine, tryptophan, threonine, isoleucine, and valine, in which these amino acids are generally deficient in cereal grains (Yildiz \& Todorov, 2014). However, with an increasing demand on soybean for animal feed and other purposes, and on the other hand, risks that may limit soybean production such as soil degradation, global warming (Hao et al., 2010), etc., there is an urgent need to search for alternative protein sources other than soybean.

Beans are generally known for their high protein contents due to their symbiotic relationships with nitrogen fixing bacteria, i.e. Rhizobium sp. that are able to take up nitrogen from the air, thus have the capacity to accumulate more nitrogenous compounds in the tissue (Goh et al., 2016). A number of beans available in Indonesia are redbean (Phaseolus vulgaris), groundnut (Arachis hypogaea), pigeonpea (Cajanus cajan), cowpea (Vigna unguiculata), bambarabean (Vigna subterranea), and mungbean (Phaseolus radiatus). Although these beans have been traditionally used for human consumption in Indonesia (Haliza et al., 2007; 2010), they are rarely used as animal feed. Furthermore, the informations about their nutritional contents, qualities, and utilizations for animals are very limited. Therefore this experiment aimed to determine nutrient content, protein fraction, and in vitro rumen fermentation of some alternative beans in comparison to soybean as a reference of commonly used protein supplement.

\section{MATERIALS AND METHODS}

\section{Sample Collection and Preparation}

Samples used in the present experiment were napier grass (Pennisetum purpureum), soybean (Glycine max), redbean (Phaseolus vulgaris), groundnut (Arachis hypogaea), pigeonpea (Cajanus cajan), cowpea (Vigna unguiculata), bambarabean (Vigna subterranea), and mungbean (Vigna radiata). Napier grass was collected from experimental station of Faculty of Animal Science, Bogor Agricultural University, and the beans were purchased from a traditional market in Bekasi, Indonesia.
All samples were immediately oven-dried at $60{ }^{\circ} \mathrm{C}$ for $24 \mathrm{~h}$ and then ground to pass a $1 \mathrm{~mm}$ sieve for further chemical composition analysis and in vitro incubation.

\section{Chemical Composition Determination}

Samples were determined for their dry matter $(\mathrm{DM})$, organic matter $(\mathrm{OM})$, crude protein $(\mathrm{CP})$, crude fiber (CF), and ether extract (EE) contents according to AOAC (2005). An oven at $105{ }^{\circ} \mathrm{C}$ and a furnace at 550 ${ }^{\circ} \mathrm{C}$ were employed to determine DM and OM contents of samples, respectively. Contents of $\mathrm{CP}$ and EE were determined by using micro-Kjeldahl and Soxhlet extraction apparatus, respectively. Sequential digestion with $\mathrm{H}_{2} \mathrm{SO}_{4}$ and $\mathrm{NaOH}$ solutions was performed to obtain $\mathrm{CF}$. Neutral detergent fiber (NDF) and acid detergent fiber (ADF) were determined by following the procedures of Van Soest et al. (1991). Analysis of NDF was performed without using $\alpha$-amylase and sodium sulfite and expressed exclusive of residual ash. Determination of ADF was similar to NDF except that the solution used was acid detergent solution. Gross energy was determined by using a bomb calorimeter.

Determination of CP fraction followed the protocol of Licitra et al. (1996) that is based on the original Cornell Net Carbohydrate and Protein System (CNCPS; Sniffen et al., 1992). The CP was divided into three main fractions, i.e. fraction A (non-protein nitrogen, NPN), fraction B (true protein), and fraction C (unavailable protein). Fraction B is further divided into three fractions namely B1, B2, and B3 in which they have different degradation rates in the rumen. Fraction B1 is a rapidly degraded CP in the rumen, whereas B2 and B3 are intermediately and slowly degraded $\mathrm{CP}$, respectively. Fraction A was obtained by precipitating true protein with trichloroacetic acid (TCA); it was calculated by the difference between $\mathrm{CP}$ and the precipitated true protein. Fraction $C$ is regarded as acid detergent insoluble crude protein (ADICP) and was determined by measuring $\mathrm{CP}$ content of ADF. Similar to ADICP, neutral detergent insoluble crude protein (NDICP) was determined by measuring $\mathrm{CP}$ content of NDF. Procedures for ADICP and NDICP measurements were adopted according to Jayanegara et al. (2016). Determination of B1, B2, and B3 fractions require determination of soluble crude protein (SCP). The SCP is defined as true protein soluble in buffer at rumen $\mathrm{pH}$. It was measured by mixing $0.5 \mathrm{~g}$ sample with $50 \mathrm{~mL}$ borate-phosphate buffer and $1 \mathrm{~mL}$ of $10 \%$ sodium azide solution. Subsequently the B fractions were calculated as follow:

$$
\begin{aligned}
& \mathrm{B} 1=\mathrm{SCP}-\mathrm{NPN}(\text { fraction } \mathrm{A}) \\
& \mathrm{B} 2=\mathrm{CP}-\mathrm{SCP}-\mathrm{NDICP} \\
& \mathrm{B} 3=\mathrm{NDICP}-\mathrm{ADICP}(\text { fraction } \mathrm{C})
\end{aligned}
$$

All of the chemical composition analyses were performed in duplicate. Proximate composition and Van Soest's fiber fractions were expressed as $\mathrm{g} / \mathrm{kg} \mathrm{DM}$ whereas fiber fractions were expressed as proportions to their corresponding $\mathrm{CP}$ contents $(\mathrm{g} / \mathrm{kg} \mathrm{CP})$.

\section{In Vitro Rumen Fermentation}

The ground samples were evaluated for their 
fermentation characteristics and digestibility by using a two-stage in vitro rumen fermentation technique (Tilley \& Terry, 1963). An amount of $0.5 \mathrm{~g}$ sample was inserted into a fermentation glass tube and added with $40 \mathrm{~mL}$ McDougall's buffer. About $10 \mathrm{ml}$ of rumen fluid was then added into the tube. Rumen fluid was obtained from two fistulated Ongole crossbred cattle, taken through the fistula before morning feeding. The cattle were cared for according to animal welfare standard of LIPI Cibinong Bogor. All tubes were continuously flushed with $\mathrm{CO}_{2}$ for $30 \mathrm{~s}$ to ensure anaerobic condition and immediately closed with ventilated rubbers. The in vitro incubation was performed in three consecutive runs (replicates) at different weeks in which each sample per run was represented by four fermentation tubes; two tubes were completed after $48 \mathrm{~h}$ incubation with buffered-rumen fluid (first stage) and the remaining tubes were continued for another $48 \mathrm{~h}$ incubation with pepsin- $\mathrm{HCl}$ solution (second stage). After the first stage of incubation, the tubes were centrifuged at 4,000 rpm for $10 \mathrm{~min}$. The supernatant was taken for subsequent VFA analysis and determination of ammonia concentration by using gas chromatography technique and Conway micro-diffusion method, respectively. The residue was analysed for $\mathrm{DM}, \mathrm{OM}$, and $\mathrm{CP}$ to obtain DM degradability (DMDe), OM degradability (OMDe), and $\mathrm{CP}$ degradability (CPDe) values, respectively. In the second stage of in vitro fermentation, the supernatants in the remaining tubes were discarded after centrifugation. Subsequently, an amount of $50 \mathrm{~mL}$ pepsin- $\mathrm{HCl} 0.2 \%$ solution was added into each tube and incubation was performed for another $48 \mathrm{~h}$, but without closing with the ventilated rubbers. The residue was separated with supernatant through filtration using Whatman paper no. 41 and analysed for DM, OM, and CP to obtain DM digestibility (DMDi), OM digestibility (OMDi), and $\mathrm{CP}$ digestibility (CPDi) values.

\section{Statistical Analysis}

Chemical composition data were descriptively tabulated. In vitro incubation data were analysed by analysis of variance (ANOVA) following a randomized complete block design. Different batches of rumen fluid (taken at different weeks) served as the blocks. The fol- lowing statistical model was employed:

$$
Y_{i j}=\mu+\tau_{i}+\beta_{j}+\varepsilon_{i j}
$$

where $Y_{i j}$ is the observed value for $i^{\text {th }}$ treatment and $j^{\text {th }}$ replicate, $\mu$ is the overall mean, $\tau_{i}$ is the treatment effect, $\beta_{\mathrm{j}}$ is the block effect (replicate) and $\varepsilon_{\mathrm{ij}}$ is the random residual error. The significancy was stated when the ANOVA result showed $\mathrm{P}<0.05$ for a certain variable. Comparison among treatments was performed by using Duncan's multiple range test. Prior to ANOVA, the data were checked for outlier values; any values $\leq-2$ or $\geq 2$ of their standardized residuals were categorized as outliers. Pearson correlation test was applied to the data to observe relationship among chemical composition and in vitro rumen fermentation parameters. All statistical analyses were performed by employing SPSS software version 20.

\section{RESULTS}

\section{Chemical Composition}

All experimental beans contained high $\mathrm{CP}$, i.e., above $200 \mathrm{~g} / \mathrm{kg}$ DM. Soybean and groundnut had CP contents higher than $300 \mathrm{~g} / \mathrm{kg}$ DM (Table 1). Napier grass contained much higher $\mathrm{CF}, \mathrm{NDF}$, and ADF than those of the beans. Among all beans, redbean had the lowest CF and ADF contents. Other beans that had lower ADF in comparison to soybean were cowpea and mungbean. The content of EE was particularly high in groundnut and soybean. The two beans were also high in GE contents as compared to the other beans. Fraction A was high in napier grass but low in soybean (Table 2 ). Soybean contained high proportion of fraction B1 and B2, but low fraction B3 and C. High proportion of fraction B3 as well as NDICP was found in napier grass, redbean, and bambarabean. Fraction $C$ was particularly very high in napier grass. Although bambarabean and mungbean were also high in fraction $C$, their contents were approximately one-third than that of napier grass.

\section{In Vitro Rumen Fermentation}

Napier grass had the lowest DMDe and DMDi in comparison to other feeds $(\mathrm{P}<0.05$; Table 3$)$. All beans generally had high DMDe and DMDi. Among the beans,

Table 1. Chemical composition (g/kg DM) and gross energy content of some feed materials (kcal/kg DM)

\begin{tabular}{|c|c|c|c|c|c|c|c|}
\hline Feedstuff & $\mathrm{OM}$ & $\mathrm{CP}$ & $\mathrm{CF}$ & NDF & $\mathrm{ADF}$ & $\mathrm{EE}$ & GE \\
\hline Napier grass & 902 & 113 & 371 & 666 & 489 & 39.0 & 4252 \\
\hline Soybean & 952 & 377 & 93.8 & 235 & 139 & 219 & 5691 \\
\hline Redbean & 961 & 260 & 55.8 & 323 & 93.1 & 17.6 & 4474 \\
\hline Groundnut & 975 & 339 & 128 & 200 & 174 & 476 & 6997 \\
\hline Pigeonpea & 958 & 242 & 108 & 313 & 168 & 13.2 & 4257 \\
\hline Cowpea & 963 & 273 & 69.8 & 417 & 117 & 18.0 & 4684 \\
\hline Bambarabean & 950 & 237 & 76.0 & 366 & 161 & 68.9 & 4594 \\
\hline Mungbean & 965 & 266 & 58.0 & 222 & 119 & 14.7 & 4420 \\
\hline
\end{tabular}

Note: $\mathrm{DM}=$ dry matter; $\mathrm{OM}=$ organic matter; $\mathrm{CP}=$ crude protein; $\mathrm{CF}=$ crude fiber; $\mathrm{NDF}=$ neutral detergent fiber; $\mathrm{ADF}=$ acid detergent fiber; $\mathrm{EE}=\mathrm{ether}$ extract; $\mathrm{GE}=$ gross energy. 
Table 2. Protein fraction of some feed materials $(\mathrm{g} / \mathrm{kg} \mathrm{CP})$

\begin{tabular}{lcccccc}
\hline \multicolumn{1}{c}{ Feedstuff } & A & B1 & B2 & NDICP & B3 & C \\
\hline Napier grass & 315 & 49.0 & 142 & 494 & 168 & 326 \\
Soybean & 45.6 & 571 & 296 & 86.9 & 24.5 & 62.4 \\
Redbean & 182 & 543 & 54.6 & 221 & 161 & 59.8 \\
Groundnut & 146 & 577 & 169 & 109 & 28.0 & 80.8 \\
Pigeonpea & 220 & 322 & 352 & 106 & 24.4 & 81.2 \\
Cowpea & 143 & 515 & 256 & 86.9 & 27.7 & 59.3 \\
Bambarabean & 258 & 150 & 383 & 210 & 106 & 103 \\
Mungbean & 180 & 449 & 243 & 128 & 11.4 & 116 \\
\hline
\end{tabular}

Note: $\mathrm{CP}=$ crude protein; $\mathrm{A}=$ non-protein nitrogen; $\mathrm{B} 1=$ rapidly degraded protein; $\mathrm{B} 2=$ intermediately degraded protein; $\mathrm{NDICP}=$ neutral detergent insoluble crude protein; $\mathrm{B} 3=$ slowly degraded protein; $\mathrm{C}=$ unavailable protein.

redbean, pigeonpea, cowpea, and mungbean were better than soybean, groundnut, and bambarabean with regard to DMDe and DMDi values $(\mathrm{P}<0.05)$. Patterns of OMDe and OMDi values were similar to those of DMDe and DMDi, respectively. With regard to CPDe and CPDi, soybean and groundnut were superior in comparison to other beans $(\mathrm{P}<0.05)$. The lowest CPDe and CPDi were found in napier grass and followed by bambarabean. Proportions of CPDe to CPDi for napier grass, soybean, redbean, groundnut, pigeonpea, cowpea, bambarabean, and mungbean were 58\%, 92\%, 81\%, $92 \%, 70 \%, 80 \%, 64 \%$, and $82 \%$, respectively.

The highest concentration of total VFA was found in the incubation of redbean and the lowest was found in napier grass (Table 4). Groundnut produced the lowest total VFA among all experimental beans $(\mathrm{P}<0.05)$. Incubation of pigeonpea, cowpea, bambarabean, and mungbean resulted in similar total VFA concentrations. Proportion of $\mathrm{C}_{2}$ was the highest for napier grass $(\mathrm{P}<0.05)$ whereas proportion of $\mathrm{C}_{3}$ was the highest for bambarabean and redbean $(\mathrm{P}<0.05)$. The lowest propor-

Table 3. In vitro degradability and digestibility of some feed materials $(\mathrm{g} / \mathrm{kg})(\mathrm{n}=3$ replicates)

\begin{tabular}{lcccccc}
\hline \multicolumn{1}{c}{ Feedstuff } & DMDe & DMDi & OMDe & OMDi & CPDe & CPDi \\
\hline Napier grass & $266^{\mathrm{a}}$ & $475^{\mathrm{a}}$ & $260^{\mathrm{a}}$ & $49^{\mathrm{a}}$ & $244^{\mathrm{a}}$ & $422^{\mathrm{a}}$ \\
Soybean & $548^{\mathrm{b}}$ & $755^{\mathrm{c}}$ & $415^{\mathrm{bc}}$ & $740^{\mathrm{c}}$ & $796^{\mathrm{e}}$ & $861^{\mathrm{d}}$ \\
Redbean & $672^{\mathrm{c}}$ & $888^{\mathrm{d}}$ & $567^{\mathrm{d}}$ & $882^{\mathrm{d}}$ & $636^{\mathrm{d}}$ & $787^{\mathrm{c}}$ \\
Groundnut & $564^{\mathrm{b}}$ & $698^{\mathrm{b}}$ & $454^{\mathrm{c}}$ & $683^{\mathrm{b}}$ & $787^{\mathrm{e}}$ & $854^{\mathrm{d}}$ \\
Pigeonpea & $698^{\mathrm{c}}$ & $893^{\mathrm{d}}$ & $613^{\mathrm{d}}$ & $889^{\mathrm{d}}$ & $531^{\mathrm{c}}$ & $763^{\mathrm{c}}$ \\
Cowpea & $676^{\mathrm{c}}$ & $878^{\mathrm{d}}$ & $588^{\mathrm{d}}$ & $874^{\mathrm{d}}$ & $625^{\mathrm{d}}$ & $783^{\mathrm{c}}$ \\
Bambarabean & $526^{\mathrm{b}}$ & $774^{\mathrm{c}}$ & $384^{\mathrm{b}}$ & $758^{\mathrm{c}}$ & $444^{\mathrm{b}}$ & $697^{\mathrm{b}}$ \\
Mungbean & $703^{\mathrm{c}}$ & $896^{\mathrm{d}}$ & $619^{\mathrm{d}}$ & $892^{\mathrm{d}}$ & $652^{\mathrm{d}}$ & $793^{\mathrm{c}}$ \\
SEM & 21.0 & 21.4 & 21.4 & 23.8 & 26.2 & 18.7 \\
P-value & $<0.001$ & $<0.001$ & $<0.001$ & $<0.001$ & $<0.001$ & $<0.001$ \\
\hline
\end{tabular}

Note: Means in the same column with different superscripts differ significantly $(\mathrm{P}<0.05)$.

$\mathrm{DMDe}=$ dry matter degradability; $\mathrm{DMDi}=$ dry matter digestibility; $\mathrm{OMDe}=$ organic matter degradability; $\mathrm{OMDi}=$ organic matter digestibility; $\mathrm{CPDe}=$ crude protein degradability; $\mathrm{CPDi}=$ crude protein digestibility; $\mathrm{SEM}=$ standard error of mean. tion of $\mathrm{C}_{4}$ was found in napier grass incubation $(\mathrm{P}<0.05)$. All beans produced ammonia at concentrations above 20 $\mathrm{mM}$ in which soybean was superior in generating ammonia as compared to other beans $(\mathrm{P}<0.05)$. The lowest ammonia concentration among the beans was found in the incubation of bambarabean.

\section{Correlation between Chemical Composition and iIn Vitro Rumen Fermentation Parameters}

The concentration of $\mathrm{CP}$ was positively correlated with CPDe, CPDi, and ammonia concentration $(\mathrm{P}<0.01$; Table 5). Fiber components, especially $\mathrm{CF}$ and $\mathrm{ADF}$ were negatively correlated with DMDe, DMDi, OMDe, and OMDi $(\mathrm{P}<0.05)$ but positively correlated with $\mathrm{C}_{2}$ and $\mathrm{C}_{4}$ proportions $(\mathrm{P}<0.05)$. The contents of $\mathrm{EE}$ and $\mathrm{GE}$ did not have any significant correlation with in vitro rumen fermentation parameters. Protein fraction B1 was positively correlated with $\mathrm{CPDe}, \mathrm{CPDi}$, and ammonia concentration $(\mathrm{P}<0.01)$ whereas, on the contrary, NDICP was inversely related with the in vitro rumen fermentation parameters $(\mathrm{P}<0.01)$. Fraction $\mathrm{B} 3$ had no significant correlation with CPDe and CPDi but it negatively correlated with ammonia concentration $(\mathrm{P}<0.05)$. Fraction $\mathrm{C}$ was negatively correlated with $\mathrm{CPDe}, \mathrm{CPDi}$, and ammonia $(\mathrm{P}<0.05)$.

\section{DISCUSSION}

Although all alternative beans had relatively high $\mathrm{CP}$ contents, none of them had equal $\mathrm{CP}$ in comparison to soybean. Typical CP contents in redbean, groundnut, pigeonpea, cowpea, bambarabean, and mungbean are (mean \pm sd) $248 \pm 15,297 \pm 31,232 \pm 90,252 \pm 22,198 \pm 31$, and $258 \pm 28 \mathrm{~g} / \mathrm{kg} \mathrm{DM}$, respectively (FAO, 2016), in which data on $\mathrm{CP}$ contents of the beans in the present experiment were within the range reported by FAO. Protein in soybean is known to be easily degraded in the rumen and therefore it is high in the proportion of

Table 4. In vitro ruminal volatile fatty acid (VFA) profile and ammonia concentrations of some feed materials $(n=3$ replicates)

\begin{tabular}{lccccc}
\hline \multicolumn{1}{c}{ Feedstuff } & $\begin{array}{c}\text { Total VFA } \\
(\mathrm{mM})\end{array}$ & $\begin{array}{c}\text { C2 } \\
(\%)\end{array}$ & $\begin{array}{l}\text { C3 } \\
(\%)\end{array}$ & $\begin{array}{c}\text { C4 } \\
(\%)\end{array}$ & $\begin{array}{c}\text { Ammonia } \\
(\mathrm{mM})\end{array}$ \\
\hline Napier grass & $46.8^{\mathrm{a}}$ & $66.5^{\mathrm{c}}$ & $17.5^{\mathrm{a}}$ & $15.9^{\mathrm{a}}$ & $7.15^{\mathrm{a}}$ \\
Soybean & $59.5^{\mathrm{bc}}$ & $61.1^{\mathrm{ab}}$ & $18.8^{\mathrm{ab}}$ & $20.1^{\mathrm{bc}}$ & $45.6^{\mathrm{f}}$ \\
Redbean & $79.6^{\mathrm{d}}$ & $60.8^{\mathrm{ab}}$ & $20.6^{\mathrm{c}}$ & $19.0^{\mathrm{b}}$ & $31.6^{\mathrm{d}}$ \\
Groundnut & $48.6^{\mathrm{ab}}$ & $62.2^{\mathrm{b}}$ & $18.5^{\mathrm{ab}}$ & $19.4^{\mathrm{bc}}$ & $37.2^{\mathrm{e}}$ \\
Pigeonpea & $64.3^{\mathrm{c}}$ & $59.6^{\mathrm{a}}$ & $19.6^{\mathrm{bc}}$ & $20.8^{\mathrm{c}}$ & $27.6^{\mathrm{c}}$ \\
Cowpea & $65.8^{\mathrm{c}}$ & $60.6^{\mathrm{ab}}$ & $18.8^{\mathrm{ab}}$ & $19.2^{\mathrm{bc}}$ & $34.7^{\mathrm{e}}$ \\
Bambarabean & $61.6^{\mathrm{c}}$ & $60.4^{\mathrm{ab}}$ & $21.2^{\mathrm{c}}$ & $18.4^{\mathrm{b}}$ & $21.0^{\mathrm{b}}$ \\
Mungbean & $64.4^{\mathrm{c}}$ & $59.7^{\mathrm{a}}$ & $19.5^{\mathrm{bc}}$ & $20.8^{\mathrm{c}}$ & $35.4^{\mathrm{e}}$ \\
SEM & 2.13 & 0.503 & 0.311 & 0.640 & 1.73 \\
P-value & $<0.001$ & $<0.001$ & $<0.001$ & $<0.001$ & $<0.001$ \\
\hline
\end{tabular}

Note: Means in the same column with different superscripts differ significantly $(\mathrm{P}<0.05)$.

$\mathrm{C} 2=$ acetate; $\mathrm{C} 3=$ propionate; $\mathrm{C} 4=$ butyrate; $\mathrm{SEM}=$ standard error of mean. 
Table 5. Correlation coefficient between feed chemical composition and in vitro ruminal fermentation parameters $(\mathrm{n}=8)$

\begin{tabular}{lcccccccccccc}
\hline Variables & CP & CF & NDF & ADF & EE & GE & A & B1 & B2 & NDICP & B3 & C \\
\hline DMDe & 0.53 & $-0.89^{* *}$ & $-0.72^{*}$ & $-0.90^{* *}$ & -0.15 & -0.04 & -0.49 & 0.66 & 0.18 & $-0.83^{*}$ & -0.58 & $-0.85^{* *}$ \\
DMDi & 0.45 & $-0.91^{* *}$ & -0.63 & $-0.90^{* *}$ & -0.31 & -0.19 & -0.42 & 0.55 & 0.25 & $-0.77^{*}$ & -0.48 & $-0.83^{*}$ \\
OMDe & 0.35 & $-0.75^{*}$ & -0.56 & $-0.76^{*}$ & -0.28 & -0.17 & -0.36 & 0.58 & 0.07 & -0.70 & -0.53 & -0.69 \\
OMDi & 0.46 & $-0.92^{* *}$ & -0.64 & $-0.91^{* *}$ & -0.29 & -0.18 & -0.43 & 0.56 & 0.25 & $-0.78^{* *}$ & -0.49 & $-0.84^{* *}$ \\
CPDe & $0.96^{* *}$ & -0.69 & $-0.88^{* *}$ & $-0.76^{*}$ & 0.56 & 0.68 & $-0.93^{* *}$ & $0.95^{* *}$ & -0.03 & $-0.84^{* *}$ & -0.66 & $-0.80^{*}$ \\
CPDi & $0.93^{* *}$ & $-0.87^{* *}$ & $-0.93^{* *}$ & $-0.91^{* *}$ & 0.40 & 0.52 & $-0.84^{* *}$ & $0.88^{* *}$ & 0.17 & $-0.94^{* *}$ & -0.69 & $-0.94^{* *}$ \\
Total VFA & 0.16 & $-0.71^{*}$ & -0.29 & -0.70 & -0.55 & -0.45 & -0.22 & 0.37 & -0.09 & -0.36 & 0.08 & -0.60 \\
C2 & -0.57 & $0.95^{* *}$ & $0.75^{*}$ & $0.92^{* *}$ & 0.15 & 0.05 & 0.46 & -0.50 & -0.48 & $0.85^{* *}$ & 0.59 & $0.87^{* *}$ \\
C3 & 0.13 & -0.69 & -0.37 & -0.62 & -0.31 & -0.29 & 0.05 & 0.02 & 0.28 & -0.28 & 0.13 & -0.53 \\
C4 & 0.69 & $-0.80^{*}$ & $-0.86^{* *}$ & $-0.81^{*}$ & 0.07 & 0.16 & -0.63 & 0.65 & 0.38 & $-0.90^{* *}$ & $-0.80^{*}$ & $-0.79^{*}$ \\
Ammonia & $0.96^{* *}$ & $-0.74^{*}$ & $-0.86^{* *}$ & $-0.80^{*}$ & 0.41 & 0.54 & $-0.96^{* *}$ & $0.93^{* *}$ & 0.09 & $-0.88^{* *}$ & $-0.71^{*}$ & $-0.83^{*}$ \\
\hline
\end{tabular}

Note: ${ }^{*}=\mathrm{P}<0.05 ;{ }^{* *}=\mathrm{P}<0.01$.

$\mathrm{CP}=$ crude protein; $\mathrm{CF}=$ crude fiber; $\mathrm{NDF}=$ neutral detergent fiber; $\mathrm{ADF}=$ acid detergent fiber; $\mathrm{EE}=$ ether extract; $\mathrm{GE}=$ gross energy; $\mathrm{A}=$ non-protein nitrogen; $\mathrm{B} 1=$ rapidly degraded protein; $\mathrm{B} 2=$ intermediately degraded protein; $\mathrm{NDICP}=$ neutral detergent insoluble crude protein; $\mathrm{B} 3=$ slowly degraded protein; $\mathrm{C}=$ unavailable protein; $\mathrm{DMDe}=$ dry matter degradability; $\mathrm{DMDi}=$ dry matter digestibility; $\mathrm{OMDe}=$ organic matter degradability; $\mathrm{OMDi}=$ organic matter digestibility; $\mathrm{CPDe}=$ crude protein degradability; $\mathrm{CPDi}=$ crude protein digestibility; $\mathrm{VFA}=$ volatile fatty acid; $\mathrm{C} 2=$ acetate; $\mathrm{C} 3=$ propionate; C4= butyrate.

rumen degradable protein (Maxin et al., 2013; Akbarian et al., 2014). The present study confirmed such finding as shown by the high proportions of protein fraction B1 and B2 in soybean as well as by the high value of CPDe and ammonia concentration in the in vitro incubation of soybean. To our knowledge, this is the first study in Indonesia that attempted to determine various protein fractions in feedstuffs by using CNCPS method. Sniffen et al. (1992) stated that protein fraction B1 is rapidly degraded in the rumen and easily converted to peptides, amino acids, and ammonia by rumen microbes, whereas some fraction B2 is fermented in the rumen and some escapes to the next gastro-intestinal tract; this depends on the relative rates between digestion and passage. Further, the authors reported that the digestion rate constants for B1 and B2 fractions of proteinaceous feeds were $50-400 \% / \mathrm{h}$ and $2-14 \% / \mathrm{h}$, respectively (Sniffen et al., 1992). Some beans such as groundnut, pigeonpea, and cowpea showed high proportions of B1 and B2 like soybean, and hence, indicated high proportion of rumen degradable protein of the beans.

Such high proportion of degradable protein is not always good. When protein is rapidly degraded in the rumen, it may not synchron with the rate of energy and carbon provision for microbial protein synthesis, thus decreasing its conversion efficiency (Yang et al., 2010; Seo et al., 2013). This condition may lead to the accumulation of ammonia concentration in the rumen and blood stream, and when ammonia concentration in blood is above the threshold it may cause toxicity response (Bartley et al., 1976; Holder et al., 2013). Therefore a balance proportion of degradable and undegradable (but digestible) protein is important to avoid such inefficiency of microbial protein synthesis and ammonia toxicity. Wang et al. (2008) observed that high ratio of rumen degradable to rumen undegradable protein resulted in high urinary $\mathrm{N}$ and total $\mathrm{N}$ excretion. Further, a reduction of rumen degradable to rumen undegradable protein ratio improved the efficiency of $\mathrm{N}$ utilization in lactating dairy cows by decreasing $\mathrm{N}$ excretion in urine and faeces. Marghazani et al. (2012) fed different proportion of rumen undegradable protein to early lactating Sahiwal cows, i.e., 30, 40, 50, or $60 \%$ (iso-energetic and iso-proteic diets). It was observed that the cows fed with $40 \%$ rumen undegradable protein resulted in a maximum nitrogen balance and production performance. A number of treatments may be applied to shift the highly degradable protein in soybean towards more undegradable protein (by-pass protein) such as by using tannins (Jolazadeh et al., 2015) and formaldehyde (De Campeneere et al., 2010). These compounds have been known to be able to protect protein and resistant to rumen degradation by microbes (Jayanegara et al., 2013, 2015; Mahima et al., 2015). Saponins may also potentially be used for protecting protein degradation in the rumen due to their chemical interaction and inhibition on growth and activity of proteolytic microbes such as Streptococcus bovis, Butyrivibrio fibrisolvens, and Prevotella bryantii (Jayanegara et al., 2014).

Redbean and bambarabean apparently good sources of rumen undegradable protein as shown by their high proportions of fraction B3. Protein fraction B3 is insoluble in neutral detergent solution but it is soluble in acid detergent solution (Higgs et al., 2012). This fraction is slowly degraded in the rumen and the high percentage of B3 fraction escapes degradation. Digestion rate constants of protein B3 for grains, proteinaceous feeds, and forages were 0.06-0.55, 0.05-0.30, and 0.08$2.0 \% / \mathrm{h}$, respectively (Sniffen et al., 1992). However, it has to be noted that high proportion of undegradable protein is meaningless if it can not be digested and utilized in the lower gastro-intestinal tract. In the case of bambarabean, the high proportion of protein fraction $\mathrm{C}$ may limit its protein utilization. Protein fraction $\mathrm{C}$ is also known as acid detergent insoluble CP (ADICP). It represents the protein linked to lignin, tannin-protein 
complexes, heat-damaged protein, and Maillard products (Licitra et al., 1996). Further, it is highly resistant to microbial enzymes, does not provide amino acids postruminally (Sniffen et al., 1992), and generally considered unavailable for ruminants (Pelletier et al., 2010). The negative correlations between protein fraction $\mathrm{C}$ with CPDe, CPDi, and ammonia concentration in the present study confirmed such concept. Our previous study also observed a negative relationship between ADICP proportion in feedstuffs and their protein digestibility (Jayanegara et al., 2016).

Apart from the good quality of protein found in redbean, low $\mathrm{CF}$ and $\mathrm{ADF}$ contents in the bean show its potency as animal feed. Such low fiber content leads to high DMDe, DMDi, OMDe, and OMDi values since lignocellulose is known to be hardly degraded and fermented by microbes under anaerobic environment as present in the rumen (Laconi \& Jayanegara, 2015; Rouches et al., 2016). High digestibility of redbean is confirmed by the high total VFA production as an end product of microbial metabolism in the rumen, particularly from carbohydrate (both structural and non-structural) fermentation (Scharen et al., 2016). Confirming this result, a main factor determining total VFA production rate is rumen fermentable organic matter intake; there is a strong linear positive relationship between both variables (Noziere et al., 2011). In the case of groundnut that produced low total VFA, it is apparently due to the high EE or fat content. Fat in the form of triglyceride undergoes lipolysis in which fatty acids are separated from glycerol (Buccioni et al., 2012). Glycerol is further metabolized to result VFA but fatty acids are not metabolized by rumen microbes. Rather, fatty acids undergo saturation process of the double bonds known as biohydrogenation (Jayanegara et al., 2012). Therefore the contribution of fat to VFA is only from glycerol fermentation and it is considered as small amount, taking into consideration that glycerol is a three carbon molecule whereas fatty acids are medium to long chain ( $>12$ carbon molecule), depend on the origin of the fat. Additionally, one molecule of triglyceride is consisted of one molecule of glycerol and three molecules of fatty acids. The VFA is later used as energy source by the host animals and may contribute to about $70 \%$ of their total energy requirement (Bergman, 1990).

Each individual VFA has its own fate after absorption in which acetate is a precursor of milk fat and propionate is a precursor of glucose and milk sugar or lactose synthesis (Aluwong et al., 2010; Fievez et al., 2012). In the present study, higher percentage of acetate is due to higher proportion of fiber, either CF, NDF or ADF. This result is supported by a meta-analysis study of Noziere et al. (2011) that observe an increase in molar percentage of acetate with increasing proportion of digested NDF in the digested organic matter, in which the relationship is curvilinear. Further in that study, higher proportion of digested NDF in the digested organic matter results in a decrease in molar percentage of propionate. Although the correlation coefficient between fiber and propionate in this experiment was negative, it did not show any significant relationship. Bannink et al. (2006) outlined that more cellulose (fiber) fermentation will increase acetate production whereas more starch fermentation will increase propionate production. This is because of different metabolic fate between fibrolytic bacteria that produce more acetate and amylolytic bacteria that produce more propionate in the rumen (Alemu et al., 2011).

\section{CONCLUSION}

Groundnut, redbean, pigeonpea, cowpea, and mungbean have the potency as alternatives to soybean, at least partially, for ruminant feeding. All experimental beans except redbean and bambarabean are similar to soybean in which they are high with degradable protein proportion, whereas the other two beans contain substantially higher proportion of undegradable protein. Redbean in particular may strategically be used as a source of protein by-pass in ration. Although $\mathrm{CP}$ content of redbean is not as superior as soybean, it has a comparative advantage due to its low CF and ADF contents. In the case of bambarabean, its utilization may be limited since it contains considerable proportion of undigested protein (fraction C).

\section{ACKNOWLEDGEMENT}

This research was funded by Indonesian Ministry of Research, Technology, and Higher Education through "Penelitian Unggulan Perguruan Tinggi - Penelitian Unggulan Divisi" research grant. All authors are grateful to Mr. Sofyan, Mrs. Eneh, and Mrs. Dian Anggraeni for excellent technical helps during the experimental period.

\section{REFERENCES}

Akbarian, A., M. Khorvash, G. R. Ghorbani, E. Ghasemi, M. Dehghan-Banadaky, P. Shawrang, \& M. H. Ghaffari. 2014. Effects of roasting and electron beam irradiating on protein characteristics, ruminal degradability and intestinal digestibility of soybean and the performance of dairy cows. Livest. Sci. 168:45-52. http://dx.doi.org/10.1016/j. livsci.2014.07.019

Akhsan, F., L. K. Nuswantara, \& J. Achmadi. 2015. Combination of soybean meal and Hibiscus tiliaceus leaf in the goat diet: effect on some parameters of protein metabolism. J. Indonesian Trop. Anim. Agric. 40:100-106. http://dx.doi.org/10.14710/jitaa.40.2.100-106

Alemu, A. W., J. Dijkstra, A. Bannink, J. France, \& E. Kebreab. 2011. Rumen stoichiometric models and their contribution and challenges in predicting enteric methane production. Anim. Feed Sci. Technol. 166-167:761-778. http://dx.doi.org/10.1016/j.anifeedsci.2011.04.054

Aluwong, T., P. I. Kobo, \& A. Abdullahi. 2010. Volatile fatty acids production in ruminants and the role of monocarboxylate transporters: a review. African J. Biotechnol. 9:6229-6232.

AOAC. 2005. Official Methods of Analysis. 18th Edition. AOAC International, Arlington, VA, USA.

Bannink, A., J. Kogut, J. Dijkstra, J. France, E. Kebreab, A. M. Van Vuuren, \& S. Tamminga. 2006. Estimation of the stoichiometry of volatile fatty acid production in the rumen of lactating cows. J. Theor. Biol. 238:36-51. http://dx.doi.org/10.1016/j.jtbi.2005.05.026

Bartley, E. E., A. D. Davidovich, G. W. Barr, G. W. Griffel, A. 
D. Dayton, C. W. Deyoe, \& R. M. Bechtle. 1976. Ammonia toxicity in cattle. I. Rumen and blood changes associated with toxicity and treatment methods. J. Anim. Sci. 43:835841. http://dx.doi.org/10.2527/jas1976.434835x

Bergman, E. N. 1990. Energy contributions of volatile fatty acids from the gastrointestinal tract in various species. Physiol. Rev. 70:567-590.

Buccioni, A., M. Decandia, S. Minieri, G. Molle, \& A. Cabiddu. 2012. Lipid metabolism in the rumen: new insights on lipolysis and biohydrogenation with an emphasis on the role of endogenous plant factors. Anim. Feed Sci. Technol. 174:1-25. http://dx.doi.org/10.1016/j.anifeedsci.2012.02.009

Campos, A. F., O. G. Pereira, K. G. Ribeiro, S. A. Santos, \& S. D. C. Valadares Filho. 2014. Impact of replacing soybean meal in beef cattle diets with inactive dry yeast, a sugarcane by-product of ethanol distilleries and sugar mills. Anim. Feed Sci. Technol. 190:38-46. http://dx.doi. org/10.1016/j.anifeedsci.2014.01.003

De Campeneere, S., J. L. De Boever, J. M. Vanacker, \& D. L. De Brabander. 2010. Reducing nitrogen excretion and soybean meal use by feeding a lower rumen degradable protein balance and protected soybean meal to dairy cattle. Arch. Anim. Nutr. 64:85-97. http://dx.doi. org/10.1080/17450391003625011

FAO (Food and Agriculture Organization of the United Nations). 2016. Feedipedia: Animal Feed Resources Information System. http://www.feedipedia.org/ [20 June 2016].

Faradillah, F., R. Mutia, \& L. Abdullah. 2015. Substitution of soybean meal with Indigofera zollingeriana top leaf meal on egg quality of Coturnix coturnix japonica. Med. Pet. 38:192-197. http://dx.doi.org/10.5398/medpet.2015.38.3.192

Fievez, V., E. Colman, J. M. Castro-Montoya, I. Stevanov, \& B. Vlaeminck. 2012. Milk odd- and branched-chain fatty acids as biomarkers of rumen function-an update. Anim. Feed Sci. Technol. 172:51-65. http://dx.doi.org/10.1016/j. anifeedsci.2011.12.008

Goh, C. H., A. B. Nicotra, \& U. Mathesius. 2016. The presence of nodules on legume root systems can alter phenotypic plasticity in response to internal nitrogen independent of nitrogen fixation. Plant Cell Environ. 39:883-896. http://dx.doi.org/10.1111/pce.12672

Haliza, W., E. Y. Purwani, \& R. Thahir. 2007. Pemanfaatan kacang-kacangan lokal sebagai substitusi bahan baku tempe dan tahu. Buletin Teknologi Pascapanen Pertanian 3:1-8.

Haliza, W., E. Y. Purwani, \& R. Thahir. 2010. Pemanfaatan kacang-kacangan lokal mendukung diversifikasi pangan. Pengembangan Inovasi Pertanian 3:238-245.

Hao, X. Y., X. Han, H. Ju, \& E. D. Lin. 2010. Impact of climatic change on soybean production: a review. Chinese J. Appl. Ecol. 21:2697-2706.

Higgs, R. J., L. E. Chase, \& M. E. Van Amburgh. 2012. Development and evaluation of equations in the Cornell Net Carbohydrate and Protein System to predict nitrogen excretion in lactating dairy cows. J. Dairy Sci. 95:2004-2014. http://dx.doi.org/10.3168/jds.2011-4810

Holder, V. B., S. W. El-Kadi, J. M. Tricarico, E. S. Vanzant, K. R. McLeod, \& D. L. Harmon. 2013. The effects of crude protein concentration and slow release urea on nitrogen metabolism in Holstein steers. Arch. Anim. Nutr. 67:93-103. http://dx.doi.org/10.1080/1745039X.2013.773647

Jayanegara, A., M. Kreuzer, \& F. Leiber. 2012. Ruminal disappearance of polyunsaturated fatty acids and appearance of biohydrogenation products when incubating linseed oil with alpine forage plant species in vitro. Livest. Sci. 147:104-112. http://dx.doi.org/10.1016/j.livsci.2012.04.009

Jayanegara, A., S. Marquardt, E. Wina, M. Kreuzer, \& F. Leiber. 2013. In vitro indications for favourable non-additive effects on ruminal methane mitigation between high- phenolic and high-quality forages. Br. J. Nutr. 109:615-622. http://dx.doi.org/10.1017/S0007114512001742

Jayanegara, A., E. Wina, \& J. Takahashi. 2014. Meta-analysis on methane mitigating properties of saponin-rich sources in the rumen: influence of addition levels and plant sources. Asian Australas. J. Anim. Sci. 27:1426-1435. http://dx.doi.org/10.5713/ajas.2014.14086

Jayanegara, A., G. Goel, H. P. S. Makkar, \& K. Becker. 2015. Divergence between purified hydrolysable and condensed tannin effects on methane emission, rumen fermentation and microbial population in vitro. Anim. Feed Sci. Technol. 209:60-68. http://dx.doi.org/10.1016/j. anifeedsci.2015.08.002

Jayanegara, A., S. P. Dewi, N. Laylli, E. B. Laconi, Nahrowi, \& M. Ridla. 2016. Determination of cell wall protein from selected feedstuffs and its relationship with ruminal protein digestibility in vitro. Med. Pet. 39:134-140. http://dx.doi.org/10.5398/medpet.2016.39.2.134

Jolazadeh, A. R., M. Dehghan-Banadaky, \& K. Rezayazdi. 2015. Effects of soybean meal treated with tannins extracted from pistachio hulls on performance, ruminal fermentation, blood metabolites and nutrient digestion of Holstein bulls. Anim. Feed Sci. Technol. 203:33-40. http:// dx.doi.org/10.1016/j.anifeedsci.2015.02.005

Laconi, E. B., \& A. Jayanegara. 2015. Improving nutritional quality of cocoa pod (Theobroma cacao) through chemical and biological treatments for ruminant feeding: in vitro and in vivo evaluation. Asian Australas. J. Anim. Sci. 28:343-350. http://dx.doi.org/10.5713/ajas.13.0798

Licitra, G., T. M. Hernandez, \& P. J. Van Soest. 1996. Standardization of procedures for nitrogen fractionation of ruminant feeds. Anim. Feed Sci. Technol. 57:347-358. http://dx.doi.org/10.1016/0377-8401(95)00837-3

Liu, Y., N. W. Jaworski, O. J. Rojas, \& H. H. Stein. 2016. Energy concentration and amino acid digestibility in high protein canola meal, conventional canola meal, and in soybean meal fed to growing pigs. Anim. Feed Sci. Technol. 212:52-62. http://dx.doi.org/10.1016/j.anifeedsci.2015.11.017

Mahima, V. Kumar, S. K. Tomar, D. Roy, \& M. Kumar. 2015. Effect of varying levels of formaldehyde treatment of mustard oil cake on rumen fermentation, digestibility in wheat straw based total mixed diets in vitro. Vet. World 8:551555. http://dx.doi.org/10.14202/vetworld.2015.551-555

Marghazani, I. B., M. A. Jabbar, T. N. Pasha, \& M. Abdullah. 2012. Effect of supplementation with protein differ for rumen degradability on milk production and nutrients utilization in early lactating Sahiwal cows. Ital. J. Anim. Sci. 11:58-62. http://dx.doi.org/10.4081/ijas.2012.e11

Maxin, G., D. R. Ouellet, \& H. Lapierre. 2013. Ruminal degradability of dry matter, crude protein, and amino acids in soybean meal, canola meal, corn, and wheat dried distillers grains. J. Dairy Sci. 96:5151-5160. http://dx.doi. org/10.3168/jds.2012-6392

Noziere, P., F. Glasser, \& D. Sauvant. 2011. In vivo production and molar percentages of volatile fatty acids in the rumen: a quantitative review by an empirical approach. Animal 5:403-414. http://dx.doi.org/10.1017/S1751731110002016

Pelletier, S., G. F. Tremblay, A. Bertrand, G. Belanger, Y. Castonguay, \& R. Michaud. 2010. Drying procedures affect non-structural carbohydrates and other nutritive value attributes in forage samples. Anim. Feed Sci. Technol. 157:139-150. http://dx.doi.org/10.1016/i. anifeedsci.2010.02.010

Rouches, E., I. Herpoel-Gimbert, J. P. Steyer, \& H. Carrere. 2016. Improvement of anaerobic degradation by white-rot fungi pretreatment of lignocellulosic biomass: a review. Renew. Sustanable Energy Rev. 59:179-198. http://dx.doi. org/10.1016/j.rser.2015.12.317

Scharen, M., G. M. Seyfang, H. Steingass, K. Dieho, J. Dijkstra, 
L. Huther, J. Frahm, A. Beineke, D. Van Soosten, U. Meyer, G. Breves, \& S. Danicke. 2016. The effects of a ration change from a total mixed ration to pasture on rumen fermentation, volatile fatty acid absorption characteristics, and morphology of dairy cows. J. Dairy Sci. 99:3549-3565. http://dx.doi.org/10.3168/jds.2015-10450

Seo, J. K., M. H. Kim, J. Y. Yang, H. J. Kim, C. H. Lee, K. H. Kim, \& J. K. Ha. 2013. Effects of synchronicity of carbohydrate and protein degradation on rumen fermentation characteristics and microbial protein synthesis. Asian Australas. J. Anim. Sci. 26:358-365. http://dx.doi. org/10.5713/ajas.2012.12507

Sniffen, C. J., J. D. O'Connor, P. J. Van Soest, D. G. Fox, \& J. B. Russel. 1992. A net carbohydrate and protein system for evaluating cattle diets: II. Carbohydrate and protein availability. J. Anim. Sci. 70:3562-3577. http://dx.doi. org/10.2527/1992.70113562x

Tilley, J. M. A., \& R. A. Terry. 1963. A two-stage technique for the in vitro digestion of forage crops. Grass Forage Sci. 18:104-111. $\quad$ http://dx.doi.org/10.1111/j.1365-2494.1963. tb00335.x
Van Soest, P. J., J. B. Robertson, \& B. A. Lewis. 1991. Methods for dietary fiber, neutral detergent fiber, and nonstarch polysaccharides in relation to animal nutrition. J. Dairy Sci. 74:3583-3597. http://dx.doi.org/10.3168/jds. S0022-0302(91)78551-2

Vollmann, J. 2016. Soybean versus other food grain legumes: a critical appraisal of the United Nations International Year of Pulses 2016. Bodenkultur 67:17-24. http://dx.doi.org/10.1515/boku-2016-0002

Wang, C., J. X. Liu, S. W. Zhai, J. L. Lai, \& Y. M. Wu. 2008. Effects of rumen degradable protein to rumen undegradable protein ratio on nitrogen conversion of lactating dairy cows. Acta Agric. Scand. A 58:100-103. http://dx.doi.org/10.1080/09064700802187210

Yang, J. Y., J. Seo, H. J. Kim, S. Seo, \& J. K. Ha. 2010. Nutrient synchrony: is it a suitable strategy to improve nitrogen utilization and animal performance? Asian Australas. J. Anim. Sci. 23:972-979. http://dx.doi.org/10.5713/ajas.2010.r.04

Yildiz, E. \& N. Todorov. 2014. The comparison of the main protein sources for dairy cows: a review. Bulgarian J. Agric. Sci. 20:428-446. 